\title{
Alus Enduk dalam Sistem Tutur Masyarakat Sasak
}

\author{
Lalu Erwan Husnan ${ }^{1}$
}

\begin{abstract}
Abstrak
Stratifikasi bahasa Sasak tidak hanya terdiri atas tingkatan kasar, biase, alus biase, dan alus utame tapi juga alus enduk. Tingkatan terakhir terbilang baru karena penamaan baru diberikan pada tahun 2007 dan belum jelas posisinya dalam tingkata tutur Bahasa Sasak. Untuk itu, tiga desa (Bayan, Gerung, dan Tiwugalih) diambil sebagai sampel mewakili masing-masing variasi dialektal bahasa Alus bahasa Sasak. Tingkatan ini tidak memiliki kosakata sendiri seperti yang lain. Kosakata yang digunakan lebih banyak mengambil dari tingkagtan kasar dan biase dibandingkan dengan dua tingkatan yang lain. Posisi tingkatan ini berada setelah alus utame.
\end{abstract}

Kata kunci: stratifikasi, tingkatan, alus enduk, kosakata, posisi

\section{Pendahuluan}

Alus enduk merupakan salah satu tingkatan tutur dalam sistem stratifikasi bahasa Sasak. Penamaan ini diberikan oleh Husnan dkk. (2007 dan 2008). Tingkatan ini belum pernah atau tidak banyak dibicarakan oleh penulis dan pembicara sebelumnya. Dengan demikian, penamaan ini menambah daftar tingkatan kebahasaan dalam sistem stratifikasi bahasa Sasak. Stratifikasi tersebut menjadi bahasa kasar, bahasa jamaq atau biase (pergaulan), bahasa alus, dan bahasa alus utame (datu), dan bahasa alus enduk. Tingkatan tutur ini hampir tidak pernah menjadi topik pembicaran, baik pada situasi formal, informal ataupun media. Tingkatan ini sangat penting perannya dalam sistem tingkat tutur bahasa Sasak karena memiliki fungsi yang berbeda dengan tingkat tutur alus biase ataupun tingkat tutur utame.

Dalam tingkat tutur alus biase atau utame, ujaran yang diucapkan penutur berfungsi meninggikan lawan bicara, tetapi dalam tingkat tutur alus enduk, ujaran yang diucapkan berfungsi merendahkan diri. Adapun kosakata yang biasa digunakan pada tingkatan ini tidak begitu banyak dalam tingkat tutur alus biase atau utame, tapi banyak juga yang ditemukan pada tingkat tutur biase dan kasar. Sedangkan, cara pembentukan tingkat tutur ini sama seperti dua tingkat

\footnotetext{
${ }^{1}$ Pembantu Pimpinan pada Kantor Bahasa Provinsi NTB
} 
tutur alus lainnya. Perbedaannya adalah kosakata tertentu yang digunakan untuk mengganti posisi kosakata sebelumnya. Sebagai contoh, kalimat balen tiang eleq julun masjid yang tergolong alus akan berubah menjadi pondok/gubuk tiang/dewek/kaji nike julun masjid" dalam sistem tutur alus enduk. Hal ini tidak lain disebabkan dalam budaya tutur masyarakat Sasak sangat tidak sopan untuk meninggikan diri. Yang ada adalah merendahkan diri di hadapan lawan bicara yang dihormati. Kata pondok dan gubuk adalah kosakata biasa, sedangkan kata dewek dan kaji adalah kosakata utame. Keempat kosakata tersebut memiliki fungsi yang sama dalam sistem tutur alus enduk. Lebih jauh lagi, konsep tutur alus enduk berimplikasi pada penggantian kosakata yang dianggap tidak sopan dan mencari kosakata lain. Akibatnya, kosakata baru tersebut memegang peran ganda dan kosakata lama jarang digunakan.

Penggunaan tingkatan bahasa sebagai refleksi stratifikasi sosial masyarakat Sasak lebih dekat ke arah teori Semantik Equalibrium Brown dan Gilman (dalam Fasold, 1990:3). Ujaran biasa yang disimbolkan dengan 'T' mendapatkan respon alus yang disimbulkan dengan ' $\mathrm{V}$ '. Hal ini tentu tidak muncul begitu saja tapi dipengaruhi oleh banyak faktor termasuk status sosial (Husnan, 2003:13). Lebih jauh, tingkatan bahasa tersebut diikuti oleh penggunaan gelar kebangsawanan. Gelar-gelar yang dimaksud adalah raden dan lalu untuk laki-laki dan dende, baiq, dan lale untuk perempuan. Gelar-gelar tersebut nantinya akan berubah ketika laki-laki atau perempuan Sasak memiliki anak. Misalnya nama lalu berubah menjadi mamiq ditambah nama anak pertama. Namun begitu, gelar kebangsawan tersebut berbeda antara satu daerah dengan daerah lain. Perbedaan tingkatan bahasa Sasak dan perbedaan geografis penggunaan gelar untuk kelompok bangsawan berpengaruh pada perbedaan penggunaan kosakata alus bahasa Sasak.

Penelitian interdisipliner yang mengambil objek bahasa Sasak, khususnya yang berkaitan dengan tingkatan bahasa Sasak dan stratifikasi sosial masyarakat Sasak, diantaranya dilakukan oleh Farmasari (2003); Mahyuni (2006); dan Husnan, dkk. (2007 dan 2008). Penelitian yang dilakukan Farmasari dan Mahyuni difokuskan pada tingkatan bahasa Sasak di Desa Bonjeruk dan Desa Ganti Kabupaten Lombok Tengah. Lebih lanjut, Mahyuni melihat pada tingkatan bahasa Sasak dan Penggunaannya. Husnan fokus pada pemetaan kosakata alus bahasa Sasak dan sebaran penutur bahasa alus bahasa Sasak di Pulau Lombok. 
Berdasarkan uraian di atas, penelitian tentang tingkatan bahasa Sasak pernah dilakukan oleh Farmasari, Mahyuni, dan Husnan dkk. Akan tetapi, penelitian tersebut hanya berbicara pada tataran deskripsi tingkatan bahasa Sasak, pemetaan, dan sebaran penutur kosakata alus bahasa Sasak. Dua penelitian pertama sama sekali tidak menyebutkan adanya tingkatan alus enduk atau tingkatan lain selain kasar, biase, alus dan utame (datu) dalam sistem stratifikasi bahasa Sasak. Adapun penelitian ketiga menyebutkan adanya tingkatan alus enduk dalam sistem tutur bahasa Sasak, tapi tidak meberikan deskripsi dan penjelasan yang lebih detail mengingat. Hal ini tidak lain disebabkan karena penelitian yang dilakukan Husnan dkk. tidak fokus pada stratifikasi bahasa Sasak.

Dengan demikian, kajian khusus untuk mengetahui posisi dan strategi pembentukan kalimat tingkat tutur alus enduk dalam sistem tutur masyarakat Sasak diperlukan.

Daerah (enklave) yang akan dijadikan sampel dalam penelitian ini adalah desa/kelurahan. Penduduk atau masyarakat dalam desa/kelurahan tersebut masih mempertahankan atau menggunakan bahasa alus bahasa Sasak. Untuk keperluan penelitian ini, peneliti mempertimbangkan sebaran dialek: Bayan, Gerung, dan Praya, bahasa alus bahasa Sasak sesuai dengan yang pernah dilakukan oleh Husnan dkk. (2007 dan 2008). Dengan demikian, daerah pengamatan untuk penelitian ini berjumlah 3 (tiga). Daerah-daerah tersebut adalah Desa Bayan (Kecamatan Bayan), Gerung (Kecamatan Gerung), dan Desa Tiwugalih (Kecamatan Praya). Ketiga daerah tersebut mewakili masingmasing dialek bahasa alus bahasa Sasak. Adapun informan untuk setiap daerah pengamatan berjumlah 4 orang dengan kriteria sebagai berikut:

- $\quad$ berjenis kelamin pria atau wanita;

- berusia antara 20-65 tahun;

- $\quad$ orang tua, isteri atau suami informan lahir dan dibesarkan di desa tersebut;

- berpendidikan minimal sekolah dasar;

- berstatus social menengah (tidak rendah dan tidak tinggi) dengan harapan tidak terlalu tinggi mobilitasnya;

- dapat berbahasa Indonesia; dan

- $\quad$ sehat jasmani dan rohani. Sehat jasmani maksudnya tidak cacat organ bicaranya, sedangkan sehat rohani maksudnya tidak gila (diadopsi dari Mahsun, 2005). 
28| Mabasan - Vol. 5, No. 2, Juli-Desember 2011

Mengingat data yang akan dikumpulkan untuk keperluan penelitian ini adalah data kebahasaan berupa kata, frase, atau kalimat dalam sistem tutur alus enduk, maka metode yang akan digunakan untuk mengumpulkan data adalah metode cakap (interview) (Mahsun, 2005:93). Metode ini mensyaratkan peneliti untuk datang langsung ke enklave dan bertemu dengan para informan untuk diwawancarai. Teknik lanjutan yang akan digunakan adalah teknik catat dan rekam. Kedua teknik lanjutan ini berguna untuk mencatat semua fenomena yang ditemukan ketika melakukan wawanacara dengan informan. Berikutnya, apa yang diperoleh melalui metode cata dapat diverifikasi dengan hasil rekam selama wawancara. Dengan demikian data yang diperoleh lebih valid.

Data yang telah diperoleh melaui metode di atas berikutnya akan dianalisis secara deskriptif kualitatif. Analisis tersebut akan dibagi menjadi dua bagian penting. Pertama, deskripsi mengenai posisi tingkat tutur alus enduk dalam sistem tutur bahasa Sasak. Kedua, deskripsi mengenai strategi dan cara pembentukan kalimat dalam tingkat tutur alus enduk. Analisis berpatokan pada wacana tentang posisi sistem tutur alus enduk dan mempertimbangkan stratifikasi bahasa dan sosial masyarakat Sasak serta gelar kebangsawanan atau gelar seperti tuan guru, guru, dan pejabat pemerintahan yang berpengaruh pada sistem tutur tersebut. Berikutnya, data kalimat dianalisis menggunakan struktur kalimat dalam bahasa Sasak yang diungkapkan oleh Tohir (1985) dan tingkatan bahasa Sasak serta mempertimbangkan temuan empiris berupa kosakata dan kalimat bahasa alus pada penelitian 2007 dan 2008 (Husnan, dkk.).

\section{Pembahasan}

Seperti yang telah diuraikan sebelumnya, alus enduk merupakan salah satu kelas dalam sistem stratifikasi bahasa Sasak (Husnan, dkk., 2007 dan 2008). Alus Enduk merupakan tingkatan yang berfungsi merendahkan diri dan meninggikan lawan bicara. Oleh karena itu, tidak salah jika tingkatan ini ditempatkan setelah tingkatan utama. Dengan kata lain, penelitian ini telah berhasil menjawab dan mempertegas apa yang diungkapkan oleh Husnan, "Sistem tutur ini hampir tidak pernah menjadi topik pembicaran, baik pada situasi formal, informal ataupun media. Sistem tutur ini sangat penting perannya dalam sistem tingkat tutur bahasa Sasak karena memiliki fungsi yang berbeda dengan tingkat tutur alus biase ataupun tingkat tutur alus utame."

Berdasarkan analisis data frase dan kalimat sederhana yang dikumpulkan, maka alus enduk dibagi menjadi dua berdasarkan fokus topik pembicaraan: diri 
sendiri dan orang lain. Namun begitu, terdapat variasi pada kedua pembagian tersebut khususnya berkaitan dengan kosakata yang digunakan, nomina.

Sistem tutur alus enduk paling banyak ditemukan pada frase atau kalimat yang berkaitan dengan diri sendiri. Hal ini sesuai dengan definisi yang diberikan untuk tingkat tutur ini, merendahkan diri. Pada tingkat tutur biase, kata 'aku' direalisasikan dengan bentuk 'aku' atau 'kaku' atau 'epe' (khusus pada beberapa variasi dialektal), dan jika nomina ini melekat pada kata lain yang diikuti atau dalam bentuk klitik direalisasi dengan bentuk '-ku' atau '-k.' Bentuk-bentuk tersebut sering terdengar pada ungkapan atau ujaran biasa yang melibatkan dua orang atau dengan yang memiliki hubungan yang dekat atau akrab. Namun begitu, ketika dua orang atau lebih yang terlibat dalam sebuah ujaran atau percakapan, dan salah satu dari mereka memiliki status sosial lebih tinggi $(\mathrm{H})$ baik yang disebabkaan oleh faktor kebangsawan, pendidikan, jabatan, status keagamaan, maka ungkapan yang mengandung nomina 'saya' baik yang berkaitan langsung atau tidak langsung dengan pembicara $(\mathrm{H})$ akan digantikan dengan kata 'dewek,' atau 'dekaji.'

Tidak hanya sampai di situ. Kata atau frase yang mengikuti atau diikuti diusahakan diubah menjadi alus enduk dengan cara menggantikannya dengan kosakata dari tingkat biase bahkan kasar baik yang berfungsi sebagi subjek atau objek.

Pada sistem tutur alus enduk berkaitan dengan diri sendiri, ada kalanya fokus yang direndahkan itu berada pada posisi subjek. Subjeknya bisa berupa satu kata atau dalam bentuk frase.

Dewek niki nyeke berajah mace. $\quad \rightarrow$ alus enduk

(saya ini sedang belajar baca (takepan/lontar)

Tiang nyeke berajah mace. $\rightarrow$ alus biase

Saya sedang belajar membaca takepan. $\rightarrow$ semantis

Kata 'dewek' pada contoh tersebut menggantikan posisi 'aku' dan ditambah dengan pronomina 'niki.' Tambahan kata 'niki' berfungsi menekankan fokus subjek. Perhatikan juga contoh berikutnya:

Doe kaji maraq niki ruen. 
30| Mabasan - Vol. 5, No. 2, Juli-Desember 2011

Tingkatan alus enduk juga terdapat pada posisi objek pada sebuah kalimat. Maksud dari kalimat tersebut sama, yaitu merendahkan diri. Pola pertama yang ditemui adalah penggantian nomina 'aku' dengan 'kaji' sebelum atau setelah kata benda. Bentuk, "ayah membelikan saya baju" akan menjadi "amaq beliang aku baju" pada tingkatan biasa dan "mamiq tumbasan tiang kelambi," sedangkan bentuk enduknya adalah "mamiq tumbasan dewek kelambi."

Dengan kata lain, tingkatan alus enduk bisa dibentuk hanya dengan mengganti nomina 'aku' pada posisi objek dengan kosakata alus enduk. Kata pada posisi sebelum dan sesudah 'aku' bisa diganti atau tidak. Posisi nomina tersebut biasanya digantikan dengan kata atau frase. Kata pada posisi tersebut digantikan dengan nomina.

Selain perubahan pada posisi subjek dan objek, juga terdapat perubahan penuh pada kalimat untuk dijadikan bentuk alus enduk. Contoh untuk kalimat ini adalah:

$\begin{array}{ll}\begin{array}{l}\text { Doe kaji lengeq. } \\ \text { (punya saya jelek) }\end{array} & \rightarrow \text { alus enduk } \\ \text { Motor tiang baruq beli } & \rightarrow \text { alus biase } \\ \text { Motor saya bagus } & \rightarrow \text { semantis }\end{array}$

Jika dirunut ke belakang, kalimat ini diubah dari bentuk alus "Neq (motor) tiang solah," atau bisa juga merupakan sebuah respon atau tanggapan atas pujian yang ditujukan kepada pemilik motor, "Solah montorm," atau "Baru ni, piran belin."

Pada contoh tersebut, semua kosakata dalam satu kalimat alus diubah menjadi bentuk alus enduk. Kata "neq" diganti dengan bentuk "doe" sedangkan kata "tiang" dan "solah" diganti dengan bentuk "kaji" dan "lengeq". Sebagai tambahan, frase 'baruq beli' juga merupakan alus enduk. Frase tersebut menggantikan posisi 'solah' (Bagus).

Contoh lain tapi terdapat wacana baru yang muncul bisa dilihat pada kalimat berikut:

Tunggangan dewek niki nenten man lunas. $\rightarrow$ alus enduk

(Tunggangan saya ini tidak belum lunas)

Motor tiang niki nenten man lunas. $\rightarrow$ alus biase

Motor saya belum lunas $\rightarrow$ semantis 
Bentuk alus enduk ini juga muncul sebagai respon dari dua ungkapan di atas. Wacana menarik yang muncul disini adalah frase "nenten man lunas." Berbeda dengan wacana yang muncul pada contoh pertama yang hanya menampilkan kebalikan dari realita suatu benda yang dimiliki, pada contoh kedua penutur menyampaikan wacana bahwa motor baru dan bagus yang dimilikinya masih dikredit atau tidak dibeli tunai. Meskipun frase ini tidak secara langsung membalik wacana seperti contoh pertama, tapi penutur ingin menyampaikan bahwa apa yang dimilikinya sekarang meskipun baru tapi didapatkan melalui kredit dan belum lunas. Wacana seperti ini juga mensiratkan pesan penutur bahwa dia kurang mampu untuk membeli tunai sebuah motor kepada pendengarnya.

Alus enduk dalam bahasa Sasak bisa juga terjadi jika subjeknya atau fokus bahasan bukan tentang diri sendiri. Hal ini bisa terjadi karena orang lain yanga menjadi fokus bahasan memiliki pengaruh secara sosial. Pengaruh sosial seperti status sosial, pendidikan, jabatan, dan gelar kebangsawanan dan agama memengaruhi pemilihan bahasa yang digunakan.

Alus enduk dengan topik orang pertama tunggal dapat dilihat pada contoh berikut:

$\begin{array}{ll}\text { Bijen pelungguh } & \rightarrow \text { alus enduk } \\ \text { Anakk side } & \rightarrow \text { alus biase } \\ \text { (Anak-posesif Anda) } & \\ \text { Anak saya } & \rightarrow \text { semantis }\end{array}$

Pada contoh di atas, penutur menghindari penggunaan nomina saya dan mengubah kata milik saya menjadi kata milik orang ketiga tunggal. Lebih jauh, kata "pelungguh" pada contoh tersebut berfungsi menggantikan posisi nomina saya. Namun begitu, ungkapan ini dimengerti oleh pendengar. Kata "bije" sendiri merupakan bentuk alus dari "anak" (anak), "n" merupakan klitik dari "nie" (dia), dan kata "pelungguh" adalah bentuk halus dari "side" (Anda). Kata "nie" pada kalimat tersebut bermakna -nya dalam bahasa Indonesia.

Secara semantis, jika dirunut ke belakang, kalimat tersebut niatnya mau mengungkapkan makna 'anak saya'. Kalimat ini dalam bahasa Sasak biasa bisa ditulis menjadi 'Anakk' atau 'anak aku'. Dengan demikian, klitik 'n'dan kata 'pelungguh' pada pada contoh tersebut masing-masing bermakna posesif '-nya' dan Anda. 
32| Mabasan - Vol. 5, No. 2, Juli-Desember 2011

Kasus alus enduk dengan topik orang kedua tunggal sering digantikan dengan nomina orang ketiga tunggal dia, "nie" atau dengan klitik " $n$ ". Sebagai contoh, frase 'rumah kamu' direalisasikan dengan bentuk 'balen.'

$\begin{array}{ll}\text { Balen. } & \rightarrow \text { alus enduk } \\ \text { Bale kamu. } & \rightarrow \text { biase } \\ \text { Gedeng pelungguh. } & \rightarrow \text { alus biase } \\ \text { Rumah } & \rightarrow \text { posesif } \\ \text { Rumah kamu } & \rightarrow \text { semantis }\end{array}$

Bale berarti rumah dan ' $\mathrm{n}$ ' adalah klitik atau singkatan dari nie untuk nomina orang ketiga tunggal. Namun begitu, pada contoh di atas klitik ' $n$ ' pada konteks ini sekarang bermakna posesif '-nya'.

Topik orang ketiga tunggal juga ditemukan pada kalimat alus enduk. Contoh untuk ini hampir sama dengan contoh pada orang pertama tunggal.

Tanyaan : Kelas pire Diana nani?

Bijen pelungguh masih kelas sekeq. $\rightarrow$ alus enduk

Anak tiang masih kelas sekeq

$\rightarrow$ alus biase

Anak-posesif Anda masih kelas satu

Diana masih kelas Satu

$\rightarrow$ semantis

Secara leksikal (sampai kata pelungguh), tidak berbeda, tapi secara semantis berbeda. Pada topik orang ketiga tunggal, makna sesungguhnya dari kalimat tersebut adalah 'Diana (nama seseorang yang punya hubungan keluarga dengan penutur, tidak harus anak kandung) masihn kelas sekeq.

Makna seperti ini baru bisa diketahui jika dipahami konteksnya. Guna memperjelas makna semantis contoh di atas, kalimat tersebut bisa didahului dengan pertanyaan "Kelas pire Diana nani?"

Sebagai akibat dari adanya pilihan kosakata atau bahasa dalam sistem tutur (stratifikasi) bahasa Sasak, muncul beberapa kosakata yang terbilang netral. Netral di sini merupakan satu bentuk kata yang sudah mulai menurun rentang perbedaan tingkatan penggunaan dalam sistem stratifikasi bahasa Sasak. Hal ini dimungkinkan terjadi karena kosakata tersebut sering menjadi pilihan utama penutur bahasa Sasak dalam menuturkan ujaran yang mempertimbangkan tingkatan bahasa. 
Kosakata yang dimaksud adalah 'dewek', 'tiang', dan 'kaji'. Ketiga kosakata tersebut merupakan sinonim dari bentuk 'saya'. Oleh sebab itu, kosakata tersebut bisa secara arbitrer digunakan pada semua tingkatan dalam bahasa Sasak.

Mengingat dalam bahasa Sasak terdapat tingkatan atau stratifikasi kebahasaan, ketika penutur menggunakan salah satu tingkatan ketika berbicara dengan lawan bicaranya, maka secara tidak langsung dia telah menggunakan salah satu strategi tutur dalam sistem komunikasi menggunakan bahasa Sasak.

Selain tingkat tutur kasar, biase, alus biase, dan alus utama, dalam bahasa Sasak juga diketahui memiliki tingkat tutur yang disebut alus enduk (Husnan, dkk., 2007 dan 2008).

Tingkatan alus enduk merupakan satu tingkatan dalam sistem stratifikasi bahasa Sasak yang berada pada posisi setelah alus utame mirip seperti alus sor bahasa Bali. Tingkatan ini bisa dikatakan tidak memiliki kosakata khusus. Kosakata yang digunakan untuk membentuk kalimat alus enduk adalah dengan cara mengambil dari kosakata pada tingkatan yang bawah. Kosakata yang diambil sering diambil dari tingkatan kasar dan biase.

\section{Simpulan dan Saran}

\subsection{Simpulan}

Alus enduk merupakan tingkat tutur setelah alus utame dalam sistem stratifikasi bahasa Sasak. Tingkatan alus enduk tidak memiliki kosakata sendiri, tapi banyak mengambil dari kosakata kasar dan biasa serta tingkatan yang lain. Tingkatan ini memiliki fungsi merendahkan diri dan meninggikan lawan bicara.

\subsection{Saran}

Berdasarkan hasil pembahasan pada bagian terdahulu, terlihat bahwa masih terdapat celah untuk dilakukan penelitian atau kajian lebih lanjut mengenai bahasa Sasak alus terutama mencakup masalah kajian morfologi, kajian sintaksis, dan kajian semantis. 
34| Mabasan - Vol. 5, No. 2, Juli-Desember 2011

\section{DAFTAR PUSTAKA}

Farmasari, Santi. 2003. Speech Level in Sasak: a Case Study in Bonjeruk Village. Skripsi S1: FKIP-Universitas Mataram.

Fasold, Ralp W. 1990. Sociolinguistics of Language. Cambridge: Basil Balckwell Inc.

Husnan, L. Erwan. 2003. Codeswitching in Bajo Language: a Case Study in Maringkik Island East Lombok. Skripsi S1-FKIP Universitas Mataram.

Husnan, L. Erwan; Ismail, L. Muhammad; dan Hamid, Safoan Abdul. 2007. 'Distribusi dan Pemetaan Kosakata Halus Bahasa Sasak'. Laporan Penelitian: Kantor Bahasa NTB.

Husnan, L. Erwan; Hamid, Safoan Abdul; dan Mariani, Kilep. 2008. 'Penelitian Kekerabatan Bahasa: Tanah Asal dan Arah Migrasi Penutur Kosakata Alus Bahasa Sasak'. Laporan Penelitian: Kantor Bahasa NTB.

Husnan, L. Erwan; Alaini, Nining Nur; Hariro, Zamzam; Djuwarijah, Siti; dan Hakim, Lukmanul. 2010. 'Stratifikasi Sosial Etnis Sasak yang Tercermin dalam Bahasanya'. Laporan Penelitian: Kantor Bahasa NTB.

Mahsun. 2005. Metode Penelitian Bahasa: Tahapan Strategi, Metode, dan Tekniknya. Jakarta: PT Rajagrafindo Peresada.

2006. Kajian Dialektologi Didakronis bahasa Sasak di Pulau Lombok. Yogyakarta: Gama Media.

Mahyuni. 2006. Speeech Styles and Cultural Consciousness in Sasak Community.Lombok: Cerdas Press. 